\title{
Kewenangan Penanganan Perkara Tindak Pidana Pencucian Uang oleh Anggota TNI Aktif
}

\author{
Jeanny Jessica \\ Fakultas Hukum Universitas Indonesia
}

\begin{abstract}
Money laundering is an extra ordinary and transnational crime that can threaten the stability and integrity of a country's economy and even damage the joints of the country. This criminal act can be committed by all segments of society, but mostly are those who have more power and intelligence. The active Indonesian National Army (TNI) that is given more authority by the Law in Indonesia also has the potential to commit Money Laundering crime. Regulations regarding the legal process against active soldiers of the TNI who commit criminal acts are under the authority of military investigations, as stipulated in article 24 paragraph (2) of the 1945 Constitution of the Republic of Indonesia and Law Number 48 of 2009 concerning Judicial Power in conjunction with Law Number 31 of 1997 concerning Military Courts. Recently, if there are cases of active TNI soldiers who have committed criminal acts such as corruption and / or money laundering, considering that there is no specific legal framework yet, then to fill the loopholes, provisions in the Military Court Law are used.
\end{abstract}

Key words: Money Laundering; Criminal Act; Active TNI Soldiers; Military Justice.

\begin{abstract}
Abstrak
Tindak Pidana Pencucian Uang (TPPU/money laundering) merupakan extra ordinary crime dan kejahatan transnasional yang dapat mengancam stabilitas dan integritas perekonomian suatu negara bahkan dapat merusak sendi-sendi negara. Tindak pidana ini dapat dilakukan oleh segala segmen masyarakat, namun seringkali adalah yang memiliki kekuasaan dan kepintaran lebih. Tentara Nasional Indonesia (TNI) aktif yang tentu saja diberikan kewenangan lebih oleh Undang-Undang di Indonesia juga berpotensi menjadi pelaku TPPU. Pengaturan mengenai proses hukum terhadap anggota TNI aktif yang melakukan tindak pidana berada dalam kewenangan penyidikan militer, sebagaimana diatur dalam pasal 24 ayat (2) Undang-Undang Dasar Negara Republik Indonesia Tahun 1945 dan Undang-Undang Nomor 48 tahun 2009 tentang Kekuasaan Kehakiman juncto UndangUndang Nomor 31 tahun 1997 tentang Peradilan Militer. Selama ini, pada praktik penerapannya, apabila terdapat kasus anggota TNI aktif yang melakukan tindak pidana seperti korupsi dan/atau pencucian uang, mengingat hingga saat ini belum ada kerangka aturan hukumnya secara spesifik, maka guna mengisi kekosongan hukum tersebut maka digunakan ketentuan dalam Undang-Undang Peradilan Militer.
\end{abstract}

Kata Kunci: Tindak Pidana Pencucian Uang, Kejahatan, Prajurit TNI Aktif, Peradilan Militer.

\section{PENDAHULUAN}

Pencucian uang adalah tindak pidana yang dapat dilakukan oleh individu (self laundering) atau berkelompok (korporasi). dalam praktiknya pencucian uang juga tergolong sebagai kejahatan yang terorganisir (organized crime) dan kejahatan kerah putih (white collar crime) bahkan juga berdimensi internasional (transnational crime). Indonesia sudah menerapkan anti money laundering regime sejak 17 April 2002 yang ditandai dengan disahkannya Undang-Undang Nomor 15 Tahun 2002 tentang Tindak Pidana Pencucian Uang (selanjutnya disebut TPPU) sebagaimana diubah dengan Undang-Undang Nomor 25 Tahun 2003. Selanjutnya Indonesia kembali memperbaharui ketentuan pencegahan dan pemberantasan TPPU dengan menetapkan Undang-Undang Nomor 8 Tahun 2010 tentang Pencegahan dan Pemberantasan Tindak Pidana Pencucian Uang (selanjutnya disebut UU PP TPPU) dan menyesuaikan substansi dalam UU TPPU dengan 
rekomendasi yang dikeluarkan oleh Financial Action Task Force on Money laundering (FATF Recommendation).

Salah satu pembaharuan yang diatur dalam UU PP TPPU yakni adanya penambahan pemberian kewenangan kepada penyidik tindak pidana asal untuk menyidik TPPU (multi investigator). Secara teknis penyidikan TPPU oleh penyidik tindak pidana asal akan mempercepat penanganan dugaan TPPU sekaligus tindak pidana asalnya. Penyidik dapat memanfaatkan kelebihan yang tercantum dalam UU PP TPPU seperti penerobosan prinsip kerahasiaan transaksi keuangan, sistem pembuktian terbalik, dan perlindungan saksi dan juga pihak pelapor.

Dalam Pasal 2 UU PP TPPU, diatur mengenai jenis-jenis tindak pidana yang merupakan tindak pidana asal (predicate crimes) atau sumber terciptanya harta kekayaan yang menjadi obyek pencucian uang. Selanjutnya, dalam Pasal 74 UU PP TPPU menyebutkan penyidikan TPPU dilakukan oleh penyidik tindak pidana asal sesuai dengan ketentuan hukum acara dan ketentuan peraturan perundang-undangan, kecuali ditentukan lain menurut Undang-Undang ini. Sedangkan Penjelasan Pasal 74 menyebutkan bahwa yang dimaksud dengan "penyidik tindak pidana asal" adalah pejabat dari instansi yang oleh undang-undang diberi kewenangan untuk melakukan penyidikan, yaitu Kepolisian Republik Indonesia (POLRI), Kejaksaan Republik Indonesia, Komisi Pemberantasan Korupsi (KPK), Badan Narkotika Nasional (BNN), serta Direktorat Jenderal Pajak (DJP) dan Direktorat Jenderal Bea dan Cukai (DJBC). Penyidik tindak pidana asal dapat melakukan penyidikan TPPU apabila menemukan bukti permulaan yang cukup terjadinya TPPU saat melakukan penyidikan tindak pidana asal sesuai kewenangannya.

Dengan demikian, penjelasan Pasal 74 tersebut secara limitatif menyebutkan siapa saja yang dimaksud dengan penyidik tindak pidana asal. Namun, di sisi lain terdapat kemungkinan adanya dugaan TPPU yang juga dilakukan oleh individu-individu yang tunduk pada peradilan militer sehingga hal ini dapat mengakibatkan munculnya berbagai persoalan dalam penegakan hukumnya.

Penyidikan merupakan bagian dari sistem peradilan pidana, menurut Remington dan Ohlins sebagaimana dikutip oleh Aditya Wiguna Sanjaya, menyatakan bahwa sistem peradilan pidana dapat diartikan sebagai pemakaian pendekatan sistem terhadap mekanisme administratif peradilan pidana dan peradilan pidana sebagai sistem merupakan hasil interaksi antara peraturan perundangundangan, praktik administrasi dan sikap atau tingkah laku sosial. Pengertian. Sedangkan menurut Mardjono Reksodiputro sistem peradilan pidana merupakan sistem dalam suatu masyarakat untuk menanggulangi maslaah kejahatan. Menanggulangi berarti usaha untuk mengendalikan kejahatan agar berada dalam batas-batas toleransi masyarakat. Komponen dalam sistem peradilan pidana adalah lembaga kepolisian, kejaksanaan, pengadilan dan pemasyarakatan.

$$
\text { Pasal } 65 \text { ayat (2) Undang-Undang }
$$

Nomor 34 Tahun 2004 tentang TNI (selanjutnya disebut UU TNI) mengatur "Prajurit tunduk kepada kekuasaan peradilan militer dalam hal pelanggaran hukum pidana militer dan tunduk pada kekuasaan peradilan umum dalam hal pelanggaran hukum pidana umum yang diatur dengan undang-undang". Selanjutnya, di dalam ketentuan Pasal 65 ayat (3) UU TNI juga disebutkan "apabila kekuasaan peradilan umum sebagaimana dimaksud pada ayat (1) tidak berfungsi, maka prajurit tunduk di bawah kekuasaan peradilan yang diatur dengan undang-undang". Pasal 74 UU No. 34 tahun 2004 tentang TNI:

a. Ketentuan sebagaimana dimaksud dalam Pasal 65 berlaku pada saat undang-undang tentang Peradilan Militer yang baru diberlakukan.

b. Selama undang-undang peradilan militer yang baru belum dibentuk, tetap tunduk pada ketentuan Undang-Undang Nomor 31 Tahun 1997 tentang Peradilan Militer.

Oleh karenanya, apabila merujuk Pasal 74 tersebut dan mengingat ketentuan perundang-undangan mengenai peradilan militer yang baru juga belum terbentuk, apabila terdapat segala macam tindak pidana 
yang dilakukan anggota TNI baik itu tindak pidana umum maupun tindak pidana militer, maka yang berwenang melakukan penyidikan adalah penyidik dari TNI. Atas hal-hal tersebut, membuat penulis tergelitik untuk meneliti bagaimana kewenangan menyidik TPPU yang dilakukan oleh anggota Tentara Nasional Indonesia?

\section{PEMBAHASAN}

Penegakan hukum terhadap TPPU yang juga terhadap kejahatan asalnya hingga sekarang seringkali menyisakan permasalahan. Meskipun Indonesia telah melakukan kriminalisasi atas TPPU ini sejak tahun 2002, yang mungkin diantaranya adalah terkait pencucian uang yang dilakukan anggota TNI. Apabila dikaitkan dengan pelaksanaan tugas PPATK yakni analisis atau pemeriksaan laporan dan informasi sebagaimana dimaksud dalam Pasal 40 huruf d UU PP TPPU, PPATK dapat meneruskan hasil analisis atau pemeriksaan kepada penyidik.

Kemudian, permasalahan yang akan timbul antara lain apabila di dalam laporan hasil analisis atau hasil pemeriksaan transaksi keuangan oleh PPATK ditemukan adanya indikasi perbuatan pencucian uang yang dilakukan oleh anggota TNI, lalu disampaikan kepada Polri, sedangkan Polri sebagai penyidik tindak pidana asal yang seharusnya memiliki wewenang untuk melakukan penyidikan TPPU, tentunya akan terkendala regulasi terkait peradilan militer apabila pelakunya adalah anggota TNI aktif.

Kendala tersebut dapat disebabkan oleh adanya ketidakharmonisasi dan tidak adanya sinkronisasi peraturan perundangundangan, yakni antara UU Peradilan Militer, UU TNI, dan Pasal 74 UU PP TPPU. Sebagaimana telah diuraikan sebelumnya, dalam Pasal 74 UU PP TPPU yang menyebutkan bahwa penyidikan TPPU dilakukan oleh penyidik tindak pidana asal sesuai dengan ketentuan hukum acara dan ketentuan peraturan perundang-undangan, kecuali ditentukan lain menurut UndangUndang ini. Sedangkan, Penjelasan Pasal 74 menyebutkan yang dimaksud dengan "penyidik tindak pidana asal" adalah pejabat dari instansi yang oleh undang-undang diberi kewenangan untuk melakukan penyidikan, yaitu Polri, Kejaksaan, KPK, BNN, serta DJP dan DJBC. Penyidik tindak pidana asal dapat melakukan penyidikan TPPU apabila menemukan bukti permulaan yang cukup terjadinya TPPU saat melakukan penyidikan tindak pidana asal sesuai kewenangannya.

Sementara dalam UU Peradilan Militer mengatur hukum acara bagi anggota TNI khususnya dalam hal melakukan tindak pidana, mulai dari tahap penyidikan, penuntutan, pemeriksaan di pengadilan, sampai pada pelaksanaan putusan pengadilan diatur secara tersendiri. Hal ini sesuai ketentuan pasal 69 ayat (1) penyidik di lingkungan militer adalah:

a. Atasan yang berhak menghukum; dalam penjelasan umum atas UU RI No.37 tahun 1997 tentang peradilan militer diketahui kewenangan penyidikan yang ada pada atasan yang berhak menghukum tidak dilaksanakan sendiri, tetapi dilaksanakan oleh Penyidik Polisi Militer dan / atau Oditur.

b. Polisi Militer; penyidik polisi militer adalah salah seorang pejabat yang mendapat pelimpahan wewenang dari Panglima selaku atasan yang berhak menghukum tertinggi untu melakukan penyidikan terhadap tindak pidana yang dilakukan oleh prajurit.

c. Oditur; tindakan penyidikan yang dapat dilakukan oleh oditur militer adalah penyidikan yang sejak awal dilakukan sendiri oleh oditur atas perintah oditur jenderal, baik untuk tindak pidana umum maupun untuk tindak pidana tertentu.

Sebenarnya gagasan untuk menundukkan anggota TNI yang melakukan tindak pidana umum atau tindak pidana non militer di bawah kekuasaaan peradilan umum telah diamanatkan dalam ketentuan Pasal 65 ayat (2) UU TNI yang menyebutkan bahwa "Prajurit tunduk kepada kekuasaan peradilan militer dalam hal pelanggaran hukum pidana militer dan tunduk pada kekuasaan peradilan umum dalam hal pelanggaran hukum pidana umum yang diatur dengan undang-undang". Namun, ada catatan bahwa keberlakuan 
ketentuan pasal tersebut dtentukan secara bersyarat sebagaimana diatur dalam Pasal 74 UU TNI yakni:

(1) Ketentuan sebagaimana dimaksud dalam Pasal 65 berlaku pada saat undang-undang tentang Peradilan Militer yang baru diberlakukan.

(2) Selama undang-undang peradilan militer yang baru belum dibentuk, tetap tunduk pada ketentuan Undang-Undang Nomor 31 Tahun 1997 tentang Peradilan Militer.

Selanjutnya, mengingat UU peradilan militer yang baru belum terbentuk maka apabila terkait dengan segala macam tindak pidana yang dilakukan anggota TNI, baik itu tindak pidana umum maupun tindak pidana militer maka yang berwenang melakukan penyidikan adalah penyidik dari TNI. Keberlakukan substansi dalam UU TNI tersebut baru mempunyai kekuatan hukum mengikat setelah UU Peradilan Militer diubah dan diberlakukan UU Peradilan Militer yang baru. Dengan demikian kepastian hukum merupakan esensi yang sangat penting dalam hukum guna untuk mencapai tujuan utama daripada hukum yaitu keadilan. Menurut Fence. M. Wantu ukuran atau kriteria kepastian hukum itu sendiri dapat durumuskan antara lain:

a. Adanya kejelasan hukum, artinya dapat mudah dimengerti oleh rakyat;

b. Aturan hukum itu tidak bertentangan antara satu sama lain

c. Aturan hukum tidak boleh mensyaratkan perilaku di luar kemampuan subjek hukum, artinya hukum tidak boleh memerintahkan seseuatu yang tidak mungkin dilakukan;

d. Pengakuan terhadap hak dan kewajiban bagi setiap subjek hukum;

e. Adanya pengakuan dari warna negara prinsipil terhadap aturan-aturan hukum;

f. Kepastian hukum dalam hal di pengadilan ditandai dengan sikap keandirian hakim dan tidak memihak dalam menerapkan aturan-aturan hukum;

g. Kepastian hukum di pengadilan ditentukan kejelasan objek yang menjadi sengketa;

h. Kepastian hukum di pengadilan harus menentukan secara jelas objek yang dimenangkan oleh pihak-pihak yang berperkara;

i. Kepastian hukum di pengadilan ditentukan dapat dieksekusi atau dilaksanakannya putusan.

Sesuai dengan Pasal 28D ayat (1) UUD 1945 yang berbunyi "Setiap orang berhak atas pengakuan, perlindungan, dan kepastian hukum yang adil serta perlakuan yang sama di hadapan hukum. Hal ini mencerminkan bahwa selayaknya terkait upaya penegakan hukum dilakukan tanpa pandang bulu setiap warga negara yang melakukan pelanggaran hukum.

Menurut Philipus M. Hadjon kewenangan yag bersumber dari peraturan perundang-undangan tersebut diperoleh melalui tiga, yaitu:
a. atribusi;
b. delegasi; dan
c. mandat.

Menurut Hans Kelsen wajah positivis dari validitas suatu norma hukum menghungkan validitas norma hukum tersebut dengan kesesuaiannya dengan sistem peraturan peundang-undangan yang berlaku dengan norma dasar (konstitusi) suatu negara. Selanjtnya menurut Hans Kelsen bila ada dua aturan hukum yang saling kontradiktif, tentu dalam hal ini hanya satu aturan saja yang berlaku. Dengan demikian apabila terdapat aturan hukum yang saling kontradiktif maka diperlukan beberapa teori diantaranya:

1. hukum yang khusus mengesampingkan hukum yang umum;

2. hukum yang baru mengesampingkan hukum yang lama;

3. hukum yang lebih tinggi derajatnya mengesampingkan hukum yang rendah;

4. hukum yang lebih menyangkut kepentingan umum mengesampingkan hukum yang kurang menyangkut kepentingan umum;

5. mencari hukum yang paling sesuai dengn norma dasar (konstitusi).

\section{Hukum yang khusus mengesampingkan hukum yang umum}

Teori ini sering juga disebut lex specialis derogate legi generalis, yang terhadap peristiwa khusus wajib diperlukan 
undang-undang yang menyebut peristiwa itu, walaupun untuk peristiwa khusus tersebut dapat pula diperlukan undang-undang yang menyebut peristiwa yang lebih luas atau lebih umum yang dapat juga mencakup peristiwa khusus tersebut.

Dalam hal ini kedua undang-undang tersebut berisi aturan hukum yang bersifat khusus namun dalam perspektif yang berbeda. Dengan demikian asas ini tidak relevan untuk digunakan dalam mengkaji disharmonis dari kedua undang-undang ini.

\section{Hukum yang baru mengesampingkan hukum yang lama}

Disebut juga dengan istilah lex posteriore derogat legi priori dimana undangundang lain (yang lebih dahulu berlaku) yang mengatur mengenai hal tertentu, tidak berlaku lagi jika ada undang-undang yang baru telah berlaku. Syarat dari asas ini adalah hal yang diatur tentunya haruslah sama.

Berdasarkan asas tersebut dapat dikaji bahwa UU Peradilan Militer dan UU PP TPPU tidak mengatur hal yang sama. Dengan demikian asas ini tidak dapat digunakan untuk menyelesaikan disharmonis antara UU Peradilan Militer dengan UU PP TPPU.

\section{Hukum yang lebih tinggi derajatnya mengesampingkan hukum yang rendah}

Disebut juga lex superiori derogat legi inferiori, dimana asas ini digunakan apabila yang bertentangan adalah peraturan perundang-undangan yang lebih rendah dengan peraturan perundang-undangan yang lebih tinggi.

Berdaasarkan asas tersebut dapat dikaji bahwa UU Peradilan Militer dan UU PP TPPU merupakan peraturan perundang-undangan dengan jenjang/tingkat hierarki yang sama atau setara yakni sama-sama berbentuk Undang-Undang. Oleh karenanya, asas ini tidak dapat digunakan untuk menyelesaikan disharmonis antara UU Peradilan Militer dengan UU PP TPPU.

\section{Hukum yang lebih menyangkut kepentingan umum mengesampingkan}

\section{hukum yang kurang menyangkut kepentingan umum}

Pada UU Peradilan Militer dianggap menjadi alat impunitas, karena memiliki yurisdiksi untuk mengadili aparat militer yang melakukan tindak pidana umum, dan peradilan militer prosesnya tertutup, tidak transparan dan tidak mengakomodir kepentingan korban. Akibatnya, tentu saja pelaku yang diadili hanyalah pelaku lapangan, dengan vonis hukuman rendah sementara kebenaran yang asli tidak terungkap, bahkan lebih jauh lagi hak-hak korban juga tidak akan dipenuhi.

UU Peradilan Militer dapat dilihat sebagai upaya untuk melihat bahwa militer di Indonesia sebagai kekuatan yang otonom dan tidak terjamah oleh ukuran ideal demokrasi, UU Peradilan militer tidak mengatur kewenangan (yurisdiksi) berdasarkan delik yang terjadi, wewenang UU Peradilan Militer justru berbasis pada subjek atau pada siapa yang melakukan kejahatan dan/atau pelanggaran, sesungguhnya memang tidak ada alasan jelas dan pasti yang bisa dijelaskan ke masyarakat mengenai kompetensi subjektif ini, selain semata-mata kepentingan militer.

Pada aturan hukum peradilan militer kemudian digunakan kualifikasi in persona. Pengadilan Militer atau Mahkamah Militer diberlakukan terhadap anggota militer tanpa memperhitungkan delik kesalahan serta yurisdiksi atas kesalahan tersebut, yang mana hal ini berarti bahwa dimungkinkan apabila seorang anggota militer melakukan kesalahan atas delik pidana umum pada akhirnya tetap diadili dalam peradilan militer. Menurut teori dalam hukum pidana tentang batas berlakunya hukum pidana, apa yang diatur dalam UU Peradilan Militer ini menggunakan asas personaliteit (asas personalitas). Menurut Adami Chazawi, asas personaliteit adalah berlakunya hukum pidana bergantung atau mengikuti subjek hukum atau orangnya yakni warga negara dimanapun ia berada. Namun, perlu diingat bahwa penerapan asas ini dalam UU Peradilan Militer terbatas pada yustiabel subjektif yakni lingkup militer saja.

Senada dengan pendapat tersebut, menurut Mayor Chk. Parluhutan Sagala asas personalitas perorangan berarti bahwa hukum 
militer mengikuti si militer bilamana dan kemana pun dia pergi. Pendapat S. Sianturi mengenai subjektifitas tersebut adalah bahwa hukum militer pada umumnya lebih bertitik berat kepada pengguna asas perseorangan baik terhadap militer maupun terhadap setiap orang yang berada dalam suatu daerah musuh/ lawan yang dikuasai oleh satuan angkatan perang dalam hal tertentu (dalam hal ini dalam perkara tertentu), sudah sewajarnya apabila mereka ini ditundukkan kepada kekuasaan peradilan militer.

Di sisi lain dalam UU Peradilan Umum ada Perwira Penyerah Perkara (Papera) yang memiliki kewenangan diskresional untuk menentukan apakah dilanjutkan atau tidak suatu perkara ke pengadilan sebagaimana diatur dalam pasal 123 UU Peradilan Militer. Keberadaan Papera memberikan kemungkinan besar masuknya kepentigan terselubung dalam penyelesaian kasus sehingga kondisi ini menjadi penghambat proses penyelesaian kasus dan berpotensi menjadi titik awal terjadinya impunitas.

Kewenangan diskresional dari Papera tersebut memungkinkan suatu perkara tidak dilanjutkan ke pengadilan atau diselesaikan secara internal melalui hukuman disiplin. Penyelesaian internal inilah yang terbukti melahirkan impunitas dan ketidakadilan atas tindakan pidana yang dilakukan oleh anggota militer.

Sementara dalam UU PP TPPU dapat
dilihat semangat yang melatarbelakangi pembentukan undang-undang tersebut yakni TPPU tidak hanya mengancam stabilitas perekonomian tdan integritas sistem keuangan, tetapi juga dapat membahayakan sendi-sendi kehidupan bermasyarakat, bebangsa, dan bernegara berdasarkan Pancasila dan UUD 1945. Pencegahan dan pemberantasan TPPU memerlukan landasan hukum yang kuat untuk dapat memberikan jaminan kepastian hukum, efektivitas penegakan hukum serta penelusuran dan pengembalian harta kekayaan hasil tindak pidana.

Terlihat dari uraian latar belakang dibentuknya UU PP TPPU ini bahwa pembentukan UU PP TPPU bertujuan utama untuk melindungi kepentingan masyarakat, bangsa, dan negara. Dengan demikian dapat disimpulkan UU PP TPPU lebih mengutamanakan kepentingan umum daripada UU Peradilan Militer.

\section{Mencari hukum yang paling sesuai dengan norma dasar (konstitusi)}

Dalam Pasal 27 ayat (1) UUD 1945 diatur bahwa "Setiap warga negara bersamaan kedudukannya di dalam hukum dan pemerintahan dan wajib menjunjung hukum dan pemerintahan itu dengan tidak ada kecualinya". Hal ini disebut juga dengan asas persamaan di hadapan hukum (equality before the law) merupakan asas yang bersifat universal.

Dengan berlakunya kompetensi subjektif dalam UU Peradilan Militer sangat bertentangan dengan asas equality before the law sebagaimana diatur dalam konstitusi. Perubahan politik yang demokratis yang seharusnya mengedepankan persamaan di hadapan hukum ternyata tidak menyentuh anggota militer.

Sementara paradigma UU PP TPPU terlihat pada rumusan subjek normanya yakni Pasal 3, 4, 5 yang ditujukan kepada setiap orang. Menurut Maria Farida Indrati menjelaskan norma hukum adalah suatu norma hukum yang ditujukan untuk orang banyak umum dan tidak tertentuyang sering dirumuskan dengan rumusan "setiap orang", "barang siapa" dan lain sebagainya.

Rumusan tersebut diperuntukkan bagi setiap orang atau setiap warga negara secara keseluruhan. Maka dari itu, dapat disimpulkan bahwa UU PP TPPU lebih sesuai dengan amanat yang diberikan oleh Pasal 27 UUD 1945.

Kewenangan penyidik dalam lingkungan peradilan militer terhadap TPPU yang dilakukan oleh anggota TNI juga dapat dianalisis dengan menggunakan perspektif prinsip yurisdiksi (asas-asas batas berlakunya hukum pidana menurut tempat) sebagaimana dikatakan oleh Jan Remmelink yakni:

a. Asas teritorial,

Bahwa berlakunya undang-undang pidana suatu negara semata-mata digantungkan pada tempat dimana suatu tindak pidana itu 
telah dilakukan dan tempat tersebut haruslah terletak di wilayah negara yag bersangkutan. Asas ini diatur dalam Pasal 2 KUHP, yakni "Peraturan hukum pidana Indonesia berlaku terhadap tiap-tiap orang yang di dalam wilayah Indonesia melakukan delik".

b. Asas kebangsaan,

Bahwa undang-undang pidana suatu negara tetap dapat diberlakukan terhadap warga negaranya dimanapun mereka berada bahkan seandainya warga negara mereka berada di luar negeri. Asas ini diatur dalam Pasal 5 KUHP yakni "Ketentuan pidana dalam perundangundangan Republik Indonesia berlaku bagi warga negara Indonesia yang melakukan tindak pidana diluar wlayah Indonesia.

c. Asas Perlindungan,

Bahwa undang-undang pidana suatu negara tidak bergantung pada tempat seorang pelaku telah melakukan tindak pidananya, melainkan pada kepentingan hukum yang telah menjadi sasaran tindak pidana tersebut dan negara yang kepentingan hukumnya menjadi sasaran tindak pidana itu berwenang menghukum pelaku tindak pidana tersebut.

d. Asas Persamaan,

Bahwa setiap warga negara memiliki kewajiban untuk turut serta memelihara keamanan dan ketertiban dunia dengan negara lain.

Berdasarkan uraian asas sebagaimana tersebut di atas, maka apabila dikaitkan dengan dengan permasalahan TPPU yang dilakukan oleh anggota TNI bilamana dianalisis berdasarkan prinsip pendekatan yurisdiksi dimaksud, dapat dilihat bahwa UU Peradilan Militer menganut asas personalitas sedangkan UU PP TPPU menganut seluruh prinsip yurisdiksi tersebut.

Berdasarkan prinsip yurisdiksi teritorialitas, penanganan TPPU tidak memandang subjek hukum atau pelaku yang melakukan TPPU tersebut, baik sipil maupun militer selama perbuatan tersebut dilakukan di negara Indonesia maka UU PP TPPU harus diberlakukan terhadap siapapun karena TPPU merupakan kategori tindak pidana umum dan tunduk pada kekuasaaan peradilan umum. Dengan demikian, siapapun yang menjadi pelaku TPPU harus tunduk pada kekuasaaan peradilan umum termasuk juga kewenangan penyidikannya juga dilakukan oleh penyidik dalam lingkungan peradilan umum.

Melihat keseluruhan penjelasan tersebut di atas, dapat disimpulkan bahwa apabila terdapat anggota TNI yang melakukan tindak pidana umum (termasuk dalam hal ini adalah TPPU), maka kewenangan penyidikannya juga harus tunduk pada kewenangan penyidik dalam lingkungan peradilan umum. Hal senada disampaikan oleh Andi Hamzah yang mengatakan apabila akan dipisahkan tindak pidana militer dengan tindak pidana umum dalam rangka pengadilan yang akan berbeda, maka semestikanya ditentukan terlebih dahulu perbuatan mana yang termasuk tindak pidana umum. Mahfud MD mengatakan Peradilan Militer sebaiknya hanya mengadili tindak pidana yang berkaitan dengan tugas pertahanan dan kemiliteran, sedangkan untuk tindak pidana yang di luar bidang pertahanan dan kemiliteran dijadikan kompetensi absolut peradilan umum.

Dengan demikian sebelum UU Peradilan Militer baru diundangkan, maka harus ditentukan terlebih dahulu perbuatan mana yang termasuk tindak pidana militer dan dengan sendirinya yang tidak termasuk di dalam tindak pidana militer makan akan masuk ke dalam tindak pidana umum. Begitu pula dengan kewenangan penyidikan maupun peradilannya.

\section{Kesimpulan}

Berdasarkan uraian dalam pembahasan di atas, dengan melihat dari berbagai macam persepektif yang memuat diantaranya teori yang disampaikan oleh Hans Kelsen dan juga prinsip yurisdiksi, maka dapat disimpulkan bagwa TPPU yang dilakukan oleh anggota TNI seharusnya tidak tunduk pada lingkup peradilan militer, melainkan akan tunduk pada kewenangan penyidik dalam lingkungan peradilan umum.

\section{Saran}

Berdasarkan uraian dalam pembahasan di atas, saran dari penulis: 
1. Pemerintah seyogyanya menjadikan RUU tentang Peradilan Militer yang baru menjadi prioritas untuk ditetapkan, yang mana didalamnya terdapat pengaturan mengenai tindak pidana umum yang dilakukan anggota TNI maka yang berlaku adalah ketentuan peradilan umum. Urgensi ini adalah demi memberikan jaminan kepastian hukum dalam penanganan tindak pidana umum yang dilakukan anggota TNI.

2. Dalam hal RUU tentang Peradilan Militer belum direvisi, maka urgensi judicial reviu terhadap Pasal 74 UU PP TPPU perlu dilakukan Pemerintah dengan adanya penambahan kewenangan penyidik dalam lingkup peradilan umum untuk dapat melakukan penyidikan dan peradilan terhadap anggota TNI yang melakukan TPPU.

\section{DAFTAR PUSTAKA}

Aditya Wiguna Sanjaya, Kewenangan Penyidikan Tindak Pidana Pencucian Uang Oleh Anggota Tentara Nasional Indonesia, Tesis Magister Ilmu Hukum, Jember: Universitas Jember, 2015.

Al Araf, Reformasi Peradilan Militer di Indoesia, Jakarta: Imparsia, 2007.

C.S.T. Kansil dan Christine S.T. Kansil, Pengatar Ilmu Hukum Indonesia, Jakarta: Rineka Cipta, 2011.

Fence. M. Wantu, Peranan Hukum dalam Mewujudkan Kepastian Hukum Keadilan dan Kemanfaatan di Peradilan Perdata, Disertasi Program Doktor Universitas Gajah Mada, Yogyakarta, 2011.

Indonesia, Naskah Akademik Rancangan Undang-Undang Nomor 8 Tahun 2010 tentang Pencegahan dan Pemberantasan Tindak Pidana Pencucian Uang, Lembaran Negara Republik Indonesia (LNRI) Tahun 2010 Nomor 122, Tambahan Lembaran Negara (TLN) Nomor 5164.

Kontras (1), Menerobos Jalan Buntu Kajian Terhadap Sistem Peradilan Militer di Indonesia, Jakarta: Penerbit Kontras, 2009.
Mardjono Reksodiputro, Hak Asasi Manusia Dalam Sistem Peradilan Pidana, Jakarta: Pusat Pelayanan Keadilan dan Pengabdian Hukum.

Maria Farida, Ilmu Perundang-Undangan I, Yogyakarta: Kanisius, 2007.

Munir Fuady, Teori-Teori Besar Dalam Hukum, Jakarta: Kencana Prenadamedia Group, 2014.

Parluhutan Sagala, Babarapa Catatan tentang Hukum Militer.

Susno Duadji, Selayang Pandang Praktik Pencucian Uang dan Kejahatan Asal, Bandung: Books Terrace \& Library, 2008.

Titik Triwulan Tutik, Pengantar Hukum Tata Usaha Negara Indonesia, Jakarta: Prestasi Pustaka Publisher, 2010.

\section{Perundang-Undangan}

Indonesia, Undang-Undang Nomor 15 Tahun 2002 tentang Tindak Pidana Pencucian Uang, Lembaran Negara Republik Indonesia (LNRI) Tahun 2002 Nomor 30, Tambahan Lembaran Negara (TLN) Nomor 4191.

. Undang-Undang Nomor 25 Tahun 2003 tentang Perubahan atas UndangUndang Nomor 15 Tahun 2002 tentang Tindak Pidana Pencucian Uang. LN. Nomor 108 Tahun 2003. TLN Nomor 4324.

. Undang-Undang Nomor 8 Tahun 2010 tentang Pencegahan dan Pemberantasan Tindak Pidana Pencucian Uang, Lembaran Negara Republik Indonesia (LNRI) Tahun 2010 Nomor 122, Tambahan Lembaran Negara (TLN) Nomor 5164. 